\title{
VPLIVNI DEJAVNIKI POSEKA V ZASEBNIH GOZDOVIH SLOVENIJE V OBDOBJU 1995-2014
}

\section{FACTORS INFLUENCING TIMBER HARVESTING IN PRIVATE FORESTS IN SLOVENIA WITHIN THE 1995-2014 PERIOD}

\author{
Domen ČEŠAREK ${ }^{1}$, Andrej FICKO ${ }^{2}$, Andrej BONČINA ${ }^{3}$ \\ (1) Prigorica 56,1331 Dolenja vas, domen.cesarek@gmail.com \\ (2) Biotehniška fakulteta, Oddelek za gozdarstvo in obnovljive gozdne vire, andrej.ficko@bf.uni-lj.si \\ (2) Biotehniška fakulteta, Oddelek za gozdarstvo in obnovljive gozdne vire, andrej.boncina@bf.uni-lj.si
}

\begin{abstract}
IZVLEČEK
Analizirali smo posek v zasebnih gozdovih Slovenije v obdobju 1995-2014. V raziskavo smo vključili odseke, ki so v popolni zasebni lasti $(\mathrm{n}=16.234)$. Z multiplo linearno regresijo smo analizirali vpliv devetih naravnih, štirih gozdnogospodarskih in treh socioekonomskih spremenljivk na letni hektarski posek in srednje posekano drevo. Ugotovili smo, da z naraščanjem velikosti parcele in posesti narašča tudi povprečni letni posek, medtem ko se z večanjem števila (so)lastnikov v odseku, naklonom, oddaljenostjo od ceste in oddaljenostjo od naselja, potencialnim deležem smreke v odseku in deležem sukcesijskih stadijev v odseku posek zmanjšuje. Na višino poseka pozitivno vplivajo še: delež smreke v odseku, potencialna produkcijska sposobnost rastišča, razdalja od centroida odseka do najbližjega gozdnega roba, odprtost in delež bukve v odseku. Na srednje odkazano drevo najbolj pozitivno vpliva potencialna produkcijska sposobnost rastišča, najbolj negativno pa oddaljenost od ceste.
\end{abstract}

Ključne besede: gospodarjenje z gozdovi, posek, zasebni gozd, razdrobljenost posesti

\begin{abstract}
We analyzed the characteristics of timber harvesting in private forests of Slovenia during the 1995-2014 period. The survey included forest sub-compartments that had been completely privately owned in the studied period $(\mathrm{n}=16,234)$. With the multiple linear regression models we analyzed the influence of 9 natural, 4 forest-management and 3 socioeconomic variables on the amount of annual felling per hectare and the medium felled tree. We found that with the increase of the size of plots and forest property timber harvesting is increasing. Harvesting was positively influenced by the share of spruce in the growing stock, site productivity, distance to the forest edge, the openness and the share of beech in the growing stock. Harvesting was negatively influenced by inclination, distance to road and settlements, number of (co)owners, the share of spruce in the potential natural vegetation and the proportion of succession stages. The medium felled tree was positively influenced by site productivity, and most negatively by distance to the road.
\end{abstract}

Key words: forest management, timber harvesting, private forest, fragmentation of property

\section{INTRODUCTION}

1 UVOD

V Sloveniji zasebni gozdovi zajemajo $76 \%$ vseh gozdov, njihova površina znaša 886.708 ha (Poročilo Zavoda ..., 2017). Posek v zasebnih gozdovih je dolgo zaostajal za najvišjim možnim posekom, določenim v gozdnogospodarskih načrtih, vendar pa se v zadnjih letih kaže trend povečevanja količine letnega poseka. Leta 2004 je bilo v Sloveniji posekanih 2,96 milijona $\mathrm{m}^{3}$, od tega 1,81 milijona $\mathrm{m}^{3} \mathrm{v}$ zasebnih gozdovih. Leto pred obsežnim žledolomom leta 2014 je bilo v zasebnih gozdovih posekanih 2,72 milijona $\mathrm{m}^{3}$, kar je dobrih $66 \%$ več kot skoraj desetletje poprej. Leta 2014 je letni posek v zasebnih gozdovih narasel na 4,50 milijona $\mathrm{m}^{3}$ in presegel možni posek po gozdnogospodarskih načr- tih (103\%). Preseganje je bilo izrazito pri iglavcih (122 $\%$ ), pri listavcih je bil posek s 86 \% še vedno manjši od možnega. Večje količine posekanega lesa so bile zabeležene tudi v letih 2015 in 2016, saj so se posledicam žledoloma pridružile še obsežne gradacije podlubnikov (Poročilo Zavoda ..., 2017). Ob tem ne gre prezreti tudi dejstva, da analize meritev drevja na stalnih vzorčnih ploskvah kažejo, da je posek drevja v zasebnih gozdovih dejansko večji od uradno zabeleženega (Medved in Matijašić, 2008; Poročilo Zavoda ..., 2017).

Eden izmed vzrokov za neizkoriščenost možnega poseka v zasebnih gozdovih je premajhna ekonomičnost pridobivanja lesa, očitna zlasti pri sečnji tanjšega drevja (Poročilo Zavoda ..., 2017). Pomembni vzroki so tudi vse večji delež nekmečkih lastnikov gozdov, slaba 
opremljenost, starost lastnikov, nezanimanje mlajših za gospodarjenje in ekonomska neodvisnost lastnikov od gozda (Jakša, 2012). Posek v zasebnih gozdovih se je sicer najpogosteje povezoval $\mathrm{z}$ velikostjo gozdnih posesti (Winkler, 1976; Max in Lehman, 1988; Winkler in Medved, 1994; Medved, 2010) in njihovo razdrobljenostjo (Winkler, 1976; Jakša, 2012; Marenče in sod., 2012). V Sloveniji je približno 460.000 lastnikov, število gozdnih parcel pa je okoli 1,5 milijona (Medved in sod., 2010). Največji delež lastnikov $(52,4 \%)$ ima v lasti manj kot 1 ha gozda. Če prištejemo še lastnike, ki imajo v lasti 1-2 ha gozda, potem ima 67,9 \% lastnikov v lasti skupaj le 13,9 \% slovenskih gozdov (Poročilo ..., 2016). Tako velika razdrobljenost gozdne posesti $\mathrm{v}$ povezavi s številom lastnikov ter njihovo socialno in starostno strukturo gotovo otežuje uresničevanje načrtovanega poseka, gojitvenih in varstvenih del.

Vendar pa raziskav na nacionalni ravni, ki bi poskušale pojasniti vplivne dejavnike poseka, ni prav veliko. Večina študij se omejuje na manjše prostorske enote ali pa analizira zgolj trende $\mathrm{v}$ sanitarnem poseku in strukturo poseka za krajše časovno obdobje (Erzetič, 2010). Poljanec in sod. (2014) so raziskovali količino, strukturo in razporeditev sanitarnega poseka v Sloveniji v obdobju 1995-2012. Med študijami obstajajo tudi znatne razlike $\mathrm{v}$ metodoloških pristopih, kar otežuje primerjalno analizo in nedvoumne zaključke. Poje in sod. (2016) so na primer ugotavljali, kaj vpliva na obete za nadpovprečno realizacijo možnega poseka v zasebnih gozdovih v Sloveniji. Rezultati so pokazali, da na nadpovprečno realizacijo možnega poseka v odse- ku negativno vplivajo naslednji dejavniki: skalovitost, naklon, spravilna razdalja, število lastnikov in solastnikov, velikost posesti v solasti, razdalja bivanja med solastniki ter starost lastnikov in solastnikov. Dejavniki, ki pozitivno vplivajo na nadpovprečno realizacijo načrtovanega poseka, pa so naslednji: lesna zaloga, delež iglavcev v drevesni sestavi, delež gozdov v fazi pomlajevanja, odprtost gozdov, povprečna velikost gozdne parcele, površina posesti vseh lastnikov in solastnikov ter povprečna velikost posesti brez solastništva.

Glede na veliki pomen zasebnih gozdov za slovensko gozdarstvo, a hkrati slabo raziskanost dejavnikov poseka, je bila naša raziskava usmerjena $\mathrm{v}$ analizo poseka in vplivnih dejavnikov v zasebnih gozdovih Slovenije v obdobju 1995-2014. V raziskavi smo želeli preveriti ustaljeno in nepreverjeno prepričanje, da sta majhna posest in njena razdrobljenost glavna dejavnika za nizek posek v zasebnih gozdovih. V ospredju naše raziskave sta bila dva raziskovalna cilja: 1) pojasniti, kako razdrobljenost zasebne posesti vpliva na količino in strukturo poseka v zasebnih gozdovih; 2) pojasniti, kateri dejavniki vplivajo na višino poseka v zasebnih gozdovih v Sloveniji. Ob tem smo želeli preveriti naslednji hipotezi:

Povprečni letni hektarski posek v zasebnih gozdovih se razlikuje glede na stopnjo razdrobljenosti gozdov. Pričakujemo, da je povprečni letni hektarski posek $\mathrm{v}$ manjši posesti in $\mathrm{v}$ gozdovih $\mathrm{z}$ večjo razdrobljenostjo manjši kot $v$ gozdovih $\mathrm{z}$ relativno večjo in zaokroženo posestjo.

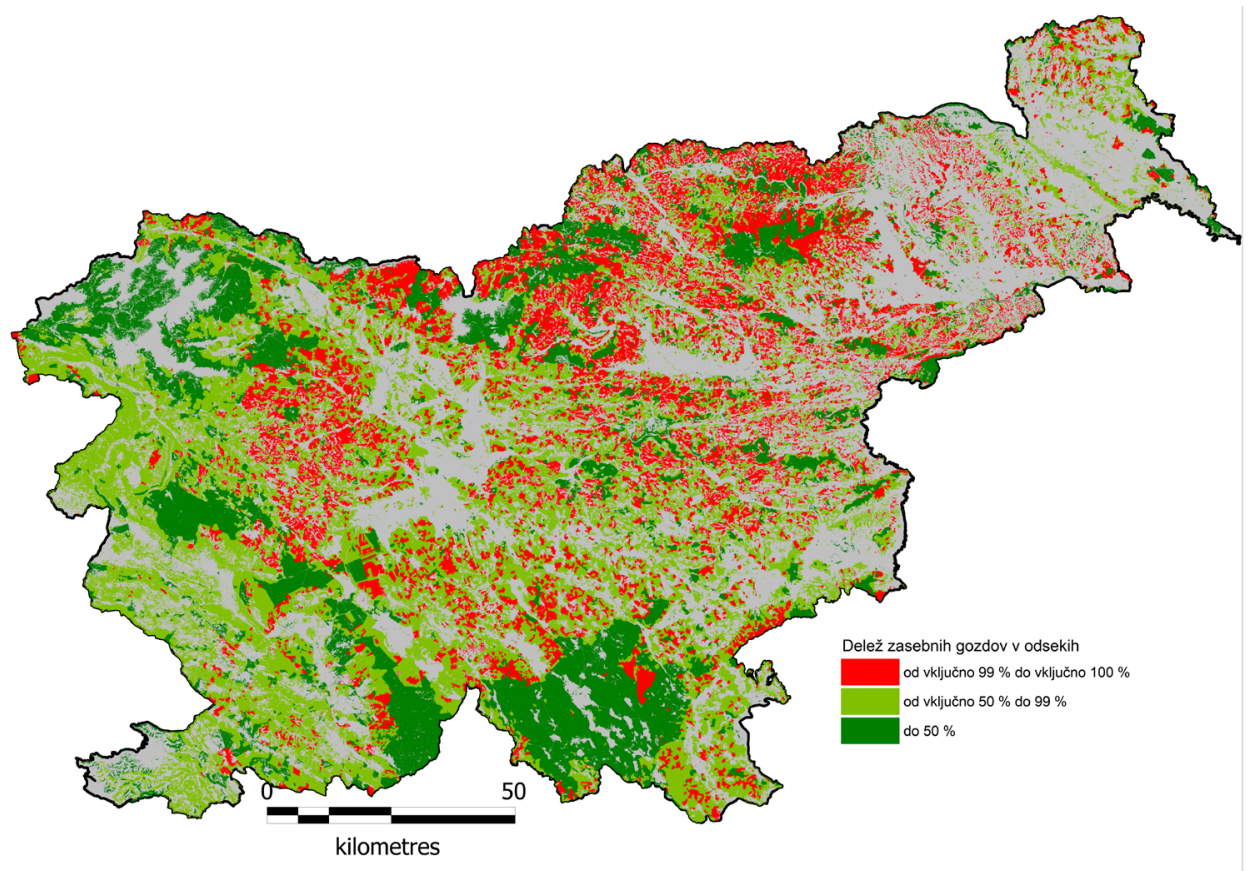

Slika 1: Delež zasebnih gozdov v odsekih

Fig. 1: Share of private forests in forest sub-compartments 
Preglednica 1: Spremenljivke, uporabljene v raziskavi

Table 1: Variables used in the study

\begin{tabular}{|c|c|c|}
\hline Spremenljivke / Variables & $\begin{array}{c}\text { Okrajšava } \\
\text { Variable code }\end{array}$ & $\begin{array}{l}\text { Podatkovna zbirka } \\
\text { Data source }\end{array}$ \\
\hline \multicolumn{3}{|l|}{ Odvisne / Dependent } \\
\hline Povprečni letni hektarski posek ( $\left.\mathrm{m}^{3} / \mathrm{ha}\right)$ / Mean annual timber harvesting $\left(\mathrm{m}^{3} / \mathrm{ha}\right)$ & POSEK $^{1}$ & Timber; Odsek \\
\hline Srednje odkazano drevo $\left(\mathrm{m}^{3}\right) /$ Mean cubic tree $\left(\mathrm{m}^{3}\right)$ & $\mathrm{SD}^{2}$ & Timber \\
\hline \multicolumn{3}{|l|}{ Neodvisne / Independent } \\
\hline \multicolumn{3}{|l|}{ Posestne / Property-related } \\
\hline Povprečna velikost parcel (ha) / Mean size of plots (ha) & PARC $^{3}$ & UGB; Odsek \\
\hline Povprečna velikost posesti (ha) / Mean property size (ha) & POSEST $^{4}$ & UGB; Odsek \\
\hline Število (so)lastnikov na 100 ha (n) / Number of forest (co)owners per 100 ha & SOLAST $^{5}$ & UGB; Odsek \\
\hline \multicolumn{3}{|l|}{ Topografske / Topographic } \\
\hline Kamnitost (\%) / Stoniness (\%) & KAM & Odsek \\
\hline Skalnatost (\%) / Rockiness (\%) & SKA & Odsek \\
\hline Nadmorska višina $(\mathrm{m})$ / Altitude $(\mathrm{m})$ & NV & UGB \\
\hline Naklon (\%) / Inclination (\%) & NAK & UGB \\
\hline \multicolumn{3}{|l|}{ Rastiščne / Site } \\
\hline Potencialni letni hektarski prirastek ( $\left.\mathrm{m}^{3} / \mathrm{ha}\right)$ / Potential mean annual increment $\left(\mathrm{m}^{3} / \mathrm{ha}\right)$ & PPS & UGB \\
\hline Potencialni delež smreke (\%) / The proportion of spruce in potential natural vegetation (\%) & SM_POT & UGB \\
\hline \multicolumn{3}{|l|}{ Sestojne / Stand } \\
\hline Delež sukcesijskih stadijev (\%) / The proportion of early successional stages (\%) & SUKC & UGB \\
\hline Delež smreke (\%) / The proportion of spruce in growing stock (\%) & SM & Odsesdv; Odsek \\
\hline Delež bukve (\%) / The proportion of beech in growing stock (\%) & $\mathrm{BU}$ & Odsesdv; Odsek \\
\hline Lesna zaloga ( $\left.\mathrm{m}^{3} / \mathrm{ha}\right)$ / Growing stock ( $\left.\mathrm{m}^{3} / \mathrm{ha}\right)$ & $\mathrm{LZ}$ & Odses; Odsek \\
\hline Lesna zaloga smreke $\left(\mathrm{m}^{3} / \mathrm{ha}\right)$ / Growing stock of spruce $\left(\mathrm{m}^{3} / \mathrm{ha}\right)$ & LZ_SM & Odsesdv; Odsek \\
\hline Lesna zaloga bukve (m³/ha) / Growing stock of beech ( $\left.\mathrm{m}^{3} / \mathrm{ha}\right)$ & LZ_BU & Odsesdv; Odsek \\
\hline \multicolumn{3}{|l|}{ Gozdnogospodarske (dostopnost) / Management and access } \\
\hline Odprtost z gozdnimi prometnicami (\% odprte površine) / Forest openess (\% of forest open) & ODP & Odsek \\
\hline $\begin{array}{l}\text { Razdalja od centroida odseka do gozdnega roba }(\mathrm{m}) \text { / Distance between the centroid of the sub-com- } \\
\text { partment and nearest forest edge }(\mathrm{m})\end{array}$ & RAZD_GR & UGB \\
\hline $\begin{array}{l}\text { Razdalja od centroida odseka do najbližje ceste }(\mathrm{m}) \text { / Distance between the centroid of the sub-com- } \\
\text { partment and nearest forest road }(\mathrm{m})\end{array}$ & RAZD_C & UGB \\
\hline $\begin{array}{l}\text { Razdalja od centroida odseka do najbližjega naselja }(\mathrm{m}) \text { / Distance between the centroid of the sub- } \\
\text { compartment and nearest settlement }(\mathrm{m})\end{array}$ & RAZD_N & UGB \\
\hline
\end{tabular}

${ }^{1}$ POSEK = skupni posek v obdobju 1995-2014 / površina odseka. $/$ POSEK = timber harvested in the period 1995-2014 / area of sub-compartment

${ }^{2} \mathrm{SD}$ = skupni posek v obdobju 1995-2014 / skupno število posekanih dreves. / SD = timber harvested in the period 1995-2014/ number of trees harvested

${ }^{3}$ PARC $=$ površina odseka $/$ število parcel $v$ odseku $= \begin{cases}1 ; & \text { PARC }<0,5 \text { ha } \\ 2 ; & \text { PARC } 0,5-1 \text { ha } . \\ 3 ; & \text { PARC }>1 \text { ha }\end{cases}$

PARC $>1 \mathrm{ha}$

$\mathrm{PARC}=$ area of the sub-compartment / number of plots in the sub-compartment $= \begin{cases}1 ; & \text { PARC }<0,5 \mathrm{ha} \\ 2 ; & \text { PARC } 0,5-1 \text { ha } \\ 3 ; & \text { PARC }>1 \text { ha }\end{cases}$

${ }^{4}$ POSEST $=$ površina odseka $/$ število posestnikov vodseku $=\left\{\begin{array}{l}1 ; \text { povprečna posest }<1 \mathrm{ha} \\ 2 ; \text { povprečna posest } 1-5 \mathrm{ha} \\ 3 ; \text { povprečna posest } 5-15 \mathrm{ha} \\ 4 ; \text { povprečna posest }>15 \mathrm{ha}\end{array}\right.$

POSEST = area of the sub-compartment / number of forest owners in the sub-compartment $=\left\{\begin{array}{l}1 ; \text { average property }<1 \text { ha } \\ 2 ; \text { average property } 1-5 \text { ha } \\ 3 ; \text { average property } 5-15 \text { ha } \\ 4 ; \text { average property }>15 \text { ha }\end{array}\right.$

1; $\quad$ SOLAST $<501 ;$ SOLAST $<50$

${ }^{5}$ SOLAST $=$ št. $($ so)lastnikov v odseku $* 100 /$ površina $=2 ; \quad$ SOLAST $50-1002 ; \quad$ SOLAST 50- 100.

3; $\quad$ SOLAST $>1003 ;$ SOLAST $>100$

$1 ;$ SOLAST $<501$; SOLAST $<50$

SOLAST $=$ Number of forest $($ co $)$ owners $* 100 /$ area $=2 ; \quad$ SOLAST $50-1002 ; \quad$ SOLAST 50-100

3; $\quad$ SOLAST $>1003 ; \quad$ SOLAST $>100$ 
Na višino poseka poleg velikosti in razdrobljenosti vplivajo naravni, gozdnogospodarski in socioekonomski dejavniki.

\section{MATERIAL IN METODE}

\section{MATERIAL AND METHODS}

Objekt naše raziskave so bili zasebni gozdovi v Sloveniji. Omejili smo se na odseke, ki so bili v obdobju 1995-2014 v celoti v zasebni lasti. Takih odsekov je bilo 16.234, analizirana površina gozdov je znašala 306.097 ha (slika 1).

Za analizo smo oblikovali relacijsko podatkovno zbirko ZASEBNI GOZDOVI (Češarek, 2017), v kateri smo zbrali podatke iz različnih podatkovnih zbirk ZGS (2014). Podatkovno zbirko smo izdelali v prostorskem informacijskem sistemu Mapinfo 12.0.2 (2013). Osnovna prostorska enota v podatkovno zbirki ZASEBNI GOZDOVI sta bila odsek in leto. Pri postavitvi podatkovne zbirke smo uporabili naslednje podatkovne vire ZGS (2014): Timber, Odsek, Odsgzd, Odsses, Odssesdv, Odssesgd. V zbirko smo uvozili izbrane podatke o poseku iz podatkovne zbirke Timber in okoljske in sociodemografske spremenljivke iz podatkovnih zbirk Skupine za urejanje gozdov in prirastoslovje (UGB, 2015). Na ravni odseka smo tako poleg identifikacijskih spremenljivk in površine zbrali podatke za šest skupin spremenljivk (preglednica 1). Analizirali smo povprečni letni hektarski posek (POSEK) (slika 2) in srednje odkazano drevo (SD).

Kot posestnik je bila upoštevana oseba, ki je na eni ali več parcelah $\mathrm{v}$ odseku prva vpisana na posestni list. Število posestnikov v odseku je tako manjše od števila vseh solastnikov gozdov v odseku. Spremenljivka POSEST ne odseva dejanske velikosti posesti posestnika, saj ima lahko ta parcele v več odsekih. Ker ni bilo na voljo podatkov o poseku na ravni posestnikov, smo povprečno velikost posesti izračunali znotraj odseka.

Spremenljivki kamnitost in skalovitost smo privzeli iz podatkovne baze Odsek (ZGS, 2014). Kamnitost in skalovitost lahko otežujeta gospodarjenje ter tako vplivata na posek. Nadmorsko višino in naklon smo privzeli iz podatkovne zbirke UGB (2015). Nadmorska višina vpliva na razširjenost gozdov, sooblikuje rastiščne razmere in drevesno sestavo ter tako posredno vpliva na preučevane spremenljivke. Naklon lahko močno vpliva na možnost gospodarjenja z gozdovi. Potencialni letni hektarski prirastek, ki smo ga privzeli iz podatkovne zbirke UGB (2015), je merilo potencialne proizvodne sposobnosti rastišča glede na dejansko drevesno sestavo in dejansko razmerje razvojnih faz. Potencialni naravni delež smreke $v$ odseku je izračunan $s$ pomočjo potencialne naravne drevesne sestave (glej Bončina in sod., 2017). Spremenljivka nam pove, kolikšen delež smrekovih rastišč je v odseku, kar praviloma kaže na skrajnostne rastiščne razmere. Spremenljivko delež sukcesijskih stadijev v odseku, ki smo jo prav tako prevzeli iz podatkovne zbirke UGB (2015), nam pove, kolikšen je delež pionirskih gozdov v odseku. Delež smreke in bukve $\mathrm{v}$ odseku smo izračunali na podlagi lesne zaloge teh dveh vrst $\mathrm{v}$ odseku in celotne lesne zaloge $\mathrm{v}$ tem odseku. Podatke smo prevzeli iz podatkovnih zbirk Odsesdv, Odses in Odsek (ZGS, 2014). Delež smreke v odseku lahko nakazuje intenzivnejše gospodarjenje zaradi ekonomskih koristi, lahko pa vpliva tudi na delež

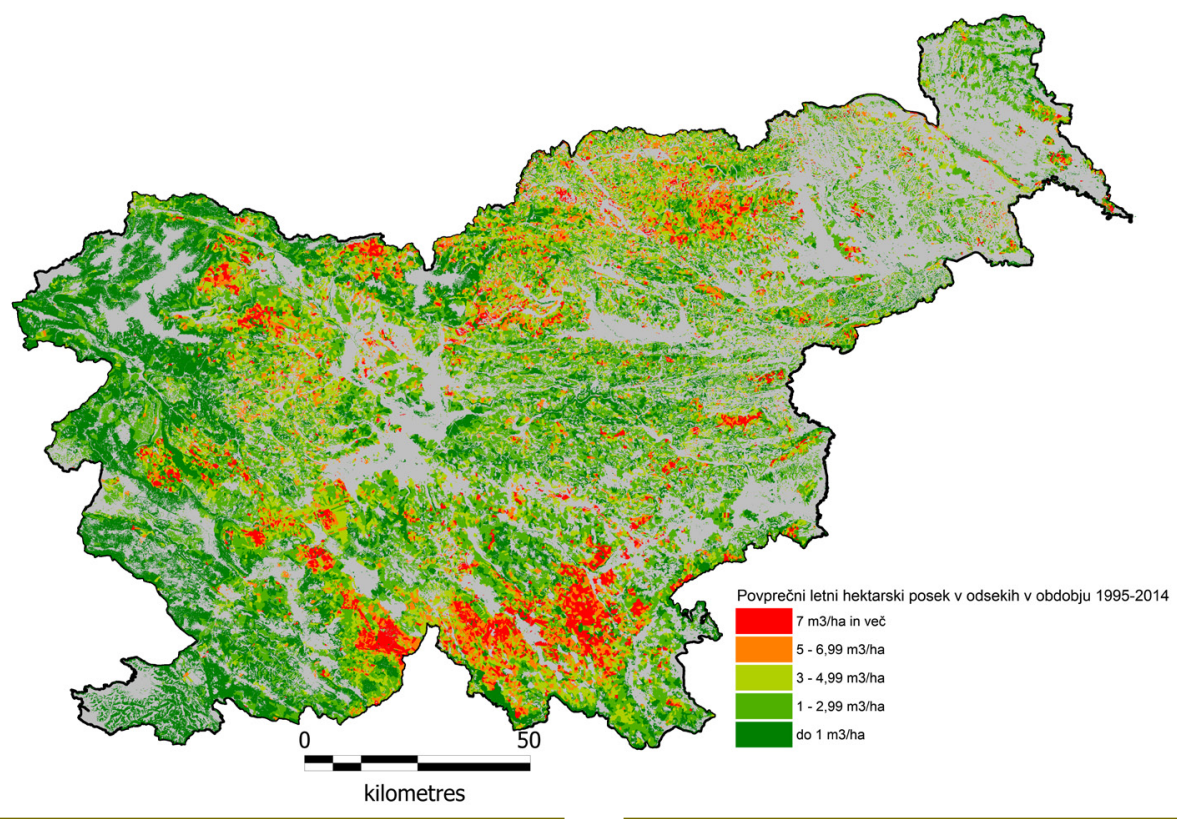

Slika 2: Povprečni letni hektarski posek (POSEK) v odsekih

Fig. 2: Mean annual timber harvesting (POSEK) in forest v obdobju 1995-2014 


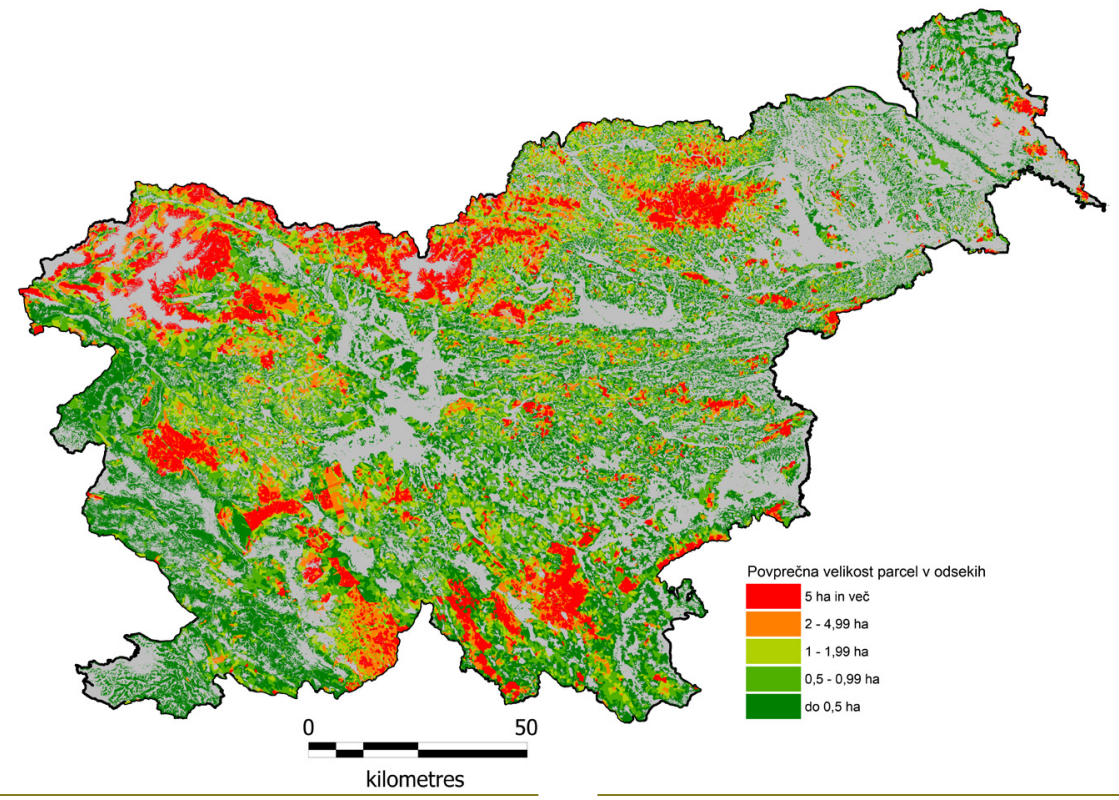

Slika 3: Povprečna velikost parcel v odsekih

$\overline{\text { sanitarne sečnje. Delež bukve lahko nakazuje stopnjo }}$ ohranjenosti gozdov. Odprtost nam pove, kolikšen delež gozda v odseku je dostopen za gospodarjenje. Podatke o odprtosti smo prevzeli iz podatkovne zbirke ZGS (2014) Odsek. Razdaljo od centroida odseka do gozdnega roba, ceste in naselja smo prevzeli iz podatkovne zbirke UGB (2015). Razdalja od gozdnega roba lahko kaže na ohranjenost gozda, saj so ob gozdnem robu pogosto pionirski sestoji in tanjša drevesa, grmičevja itd. Razdalji do ceste in naselja pa lahko kažeta na možnost ukrepanja, saj pričakujemo, da se v oddaljenih in manj dostopnih gozdovih manj gospodari.

Pri testiranju prve hipoteze smo ob upoštevanju izpolnjenosti predpostavk uporabili enofaktorsko ana-
Fig. 3: Mean size of plots in forest sub-compartments

lizo variance. Za pojasnjevanje razlik med razredi smo zaradi nehomogenosti varianc uporabili Tamhanov T2test. Pri testiranju druge hipoteze smo uporabili multiplo linearno regresijo, s katero smo preverjali vpliv neodvisnih spremenljivk na dve odvisni spremenljivki (POSEK, SD). V obeh primerih multiple regresije smo uporabili metodo »stepwise«. Pred tem smo najprej analizirali povezanost med neodvisnimi spremenljivkami in odvisnimi spremenljivkami (preglednica 2). Potem smo preverili morebitno multikolinearnost med neodvisnimi spremenljivkami. Zaradi multikolinearnosti $(r>0,60)$ smo iz nadaljnje analize izključili neodvisni spremenljivki NV in POSEST. Analize smo izpeljali s statističnim programom SPSS (IBM SPSS Statistics 20).

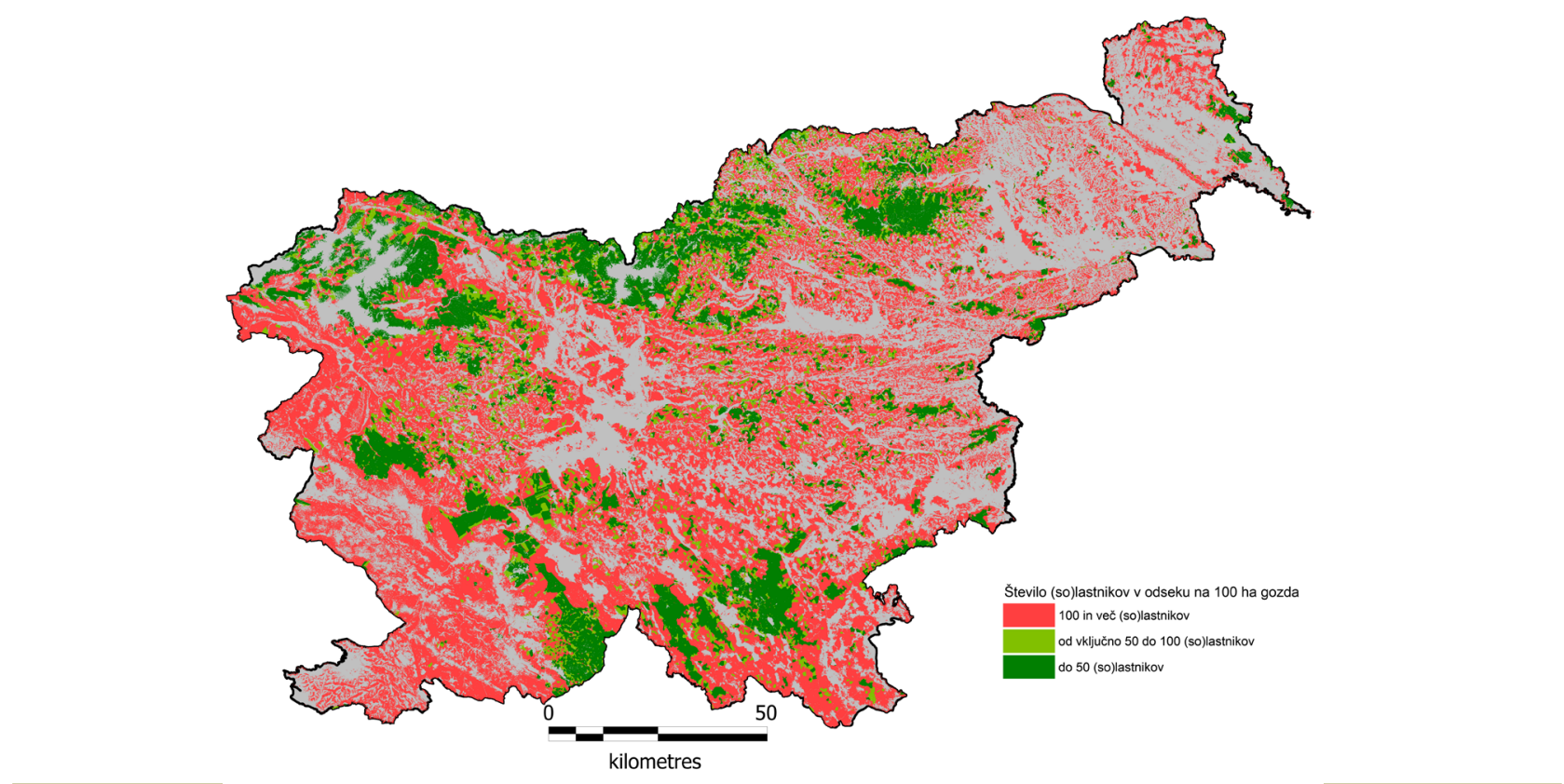

Slika 4: Število (so)lastnikov na 100 ha gozda v odseku

Fig. 4: Number of (co)owners per 100 ha of forest in the sub-compartment 
Preglednica 2: Pearsonov korelacijski koeficient (r) in stopnja značilnosti za povezanost med posameznimi neodvisnimi spremenljivkami in spremenljivko POSEK in SD (n $=16233$ odsekov)
Table 2: Pearson's correlation coefficient (r) and the significance for the relationship between independent variables and the variables POSEK and SD (n = 16,233 sub-compartments)

\begin{tabular}{|l|c|c|}
\hline \multicolumn{1}{|c|}{ Neodvisna spremenljivka / Independent variable } & POSEK & SD \\
\hline Povprečna velikost parcele v odseku / Mean size of plots & $0,190^{* * *}$ & $0,115^{* * *}$ \\
\hline Povprečna velikost posesti v odseku / Mean property size (ha) & $0,205^{* * *}$ & $0,140^{* * *}$ \\
\hline Število (so)lastnikov na 100 ha v odseku / Number of forest (co)owners per 100 ha & $-0,178^{* * *}$ & $-0,120^{* * *}$ \\
\hline Kamnitost / Stoniness & $-0,080^{* * *}$ & $-0,026^{* *}$ \\
\hline Skalnatost / Rockiness & $-0,051^{* * *}$ & $0,029^{* * *}$ \\
\hline Nadmorska višina / Altitude & $0,084^{* * *}$ & $0,139^{* * *}$ \\
\hline Naklon / Inclination & $-0,140^{* * *}$ & $0,034^{* * *}$ \\
\hline Potencialni letni hektarski prirastek / Potential mean annual increment & $0,235^{* * *}$ & $0,265^{* * *}$ \\
\hline Potencialni delež smreke v odseku / The proportion of spruce in potential natural vegetation & $0,139^{* * *}$ & $0,150^{* * *}$ \\
\hline Delež sukcesijskih stadijev v odseku / The proportion of early successional stages (\%) & $-0,103^{* * *}$ & $-0,108^{* * *}$ \\
\hline Delež smreke v odseku / The proportion of spruce in growing stock (\%) & $0,290^{* * *}$ & $0,179^{* * *}$ \\
\hline Delež bukve v odseku / The proportion of beech in growing stock (\%) & $-0,173^{* * *}$ & $-0,025^{* *}$ \\
\hline Odprtost / Forest openess & $0,198^{* * *}$ & $0,149^{* * *}$ \\
\hline $\begin{array}{l}\text { Razdalja od centroida odseka do gozdnega roba / Distance between the centroid of the sub-compartment } \\
\text { and nearest forest edge }\end{array}$ & $0,115^{* * *}$ & $0,134^{* * *}$ \\
\hline $\begin{array}{l}\text { Razdalja od centroida odseka do najbližje ceste / Distance between the centroid of the sub-compartment and } \\
\text { nearest forest road }\end{array}$ & $-0,148^{* * *}$ & $-0,127^{* * *}$ \\
\hline $\begin{array}{l}\text { Razdalja od centroida odseka do najbližjega naselja / Distance between the centroid of the sub-compartment } \\
\text { and nearest settlement }\end{array}$ & $0,098^{* * *}$ & $0,123^{* * *}$ \\
\hline
\end{tabular}

*** stopnja značilnosti $<0,001, * *$ stopnja značilnosti $<0,01$; NS ni značilne povezanosti

*** significance at $p<0.001,{ }^{* *}$ significance at $p<0.01$; NS not significant

\section{REZULTATI}

\section{RESULTS}

\subsection{Univariatne analize razlik v letnem hektar- skem poseku}

3.1 Univariate analyses of differences in annual timber harvesting per hectare

Analiza variance povprečnega letnega hektarskega poseka (POSEK) kaže, da obstajajo značilne razlike v srednjih vrednostih poseka glede na povprečno velikost parcel (preglednica 3). Povprečna vrednost poseka je najvišja v velikostnem razredu parcel 1 ha ali več, najmanjša pa v velikostnem razredu, kjer je povprečna

Preglednica 3: Testiranje vpliva razdrobljenosti parcel na količino poseka z enofaktorsko analizo variance parcela manjša kot 0,5 ha (priloga 1 ). Okvirji z ročaji nakazujejo, da se $\mathrm{z}$ večanjem razdrobljenosti posesti posek zmanjšuje (slika 5). S Tamhanovim "post hoc« T2-testom smo ugotovili, da obstajajo značilne razlike v srednjih vrednostih poseka med vsemi razredi povprečne velikosti parcel.

Analiza variance povprečnega letnega hektarskega poseka (POSEK) kaže, da obstajajo značilne razlike $v$ srednjih vrednostih poseka tudi glede na velikost posesti (preglednica 4). Večji posestniki sekajo v povprečju več kot manjši posestniki. Povprečna vrednost POSEKA je bila največja v razredu 15 ha in več, najmanjša

Table 3: Testing the influence of fragmentation of plots on the amount of timber harvested with one-way ANOVA

\begin{tabular}{|l|c|c|c|c|c|}
\hline & $\begin{array}{c}\text { Vsota kvadratov odklonov } \\
\text { Sum of squares }\end{array}$ & $\begin{array}{c}\text { Stopinje prostosti } \\
\text { Degrees of freedom }\end{array}$ & $\begin{array}{c}\text { Povprečni kvadrat } \\
\text { Mean square }\end{array}$ & $\begin{array}{c}F \\
\text { F-value }\end{array}$ & $\begin{array}{c}\text { Stopnja značilnosti } \\
\text { p-value }\end{array}$ \\
\hline Med razredi / Between & 3266 & 2 & 1633,270 & 304,959 & 0,000 \\
\hline Znotraj razredov / Within & 86928 & 16231 & 5,356 & & \\
\hline Skupaj / Total & 90195 & 16233 & & & \\
\hline
\end{tabular}

Preglednica 4: Testiranje vpliva velikosti posesti na količino poseka z enofaktorsko analizo variance
Table 4: Testing the influence of the size of the property on the amount of timber harvested with one-way ANOVA

\begin{tabular}{|l|c|c|c|c|c|}
\hline & $\begin{array}{c}\text { Vsota kvadratov odstopanj } \\
\text { Sum of squares }\end{array}$ & $\begin{array}{c}\text { Stopinje prostosti } \\
\text { Degrees of freedom }\end{array}$ & $\begin{array}{c}\text { Povprečni kvadrat } \\
\text { Mean square }\end{array}$ & $\begin{array}{c}\mathbf{F} \\
\text { F-value }\end{array}$ & $\begin{array}{c}\text { Stopnja značilnosti } \\
\text { p-value }\end{array}$ \\
\hline Med razredi / Between & 3819 & 3 & 1273,033 & 239,202 & 0,000 \\
\hline Znotraj razredov / Within & 86375 & 16230 & 5,322 & & \\
\hline Skupaj / Total & 90195 & 16233 & & & \\
\hline
\end{tabular}


pa v velikostnem razredu do 1 ha. S Tamhanovim "post hoc« T2-testom smo ugotovili, da obstajajo značilne razlike v srednjih vrednostih poseka med vsemi štirimi velikostnimi razredi posesti (slika 6).

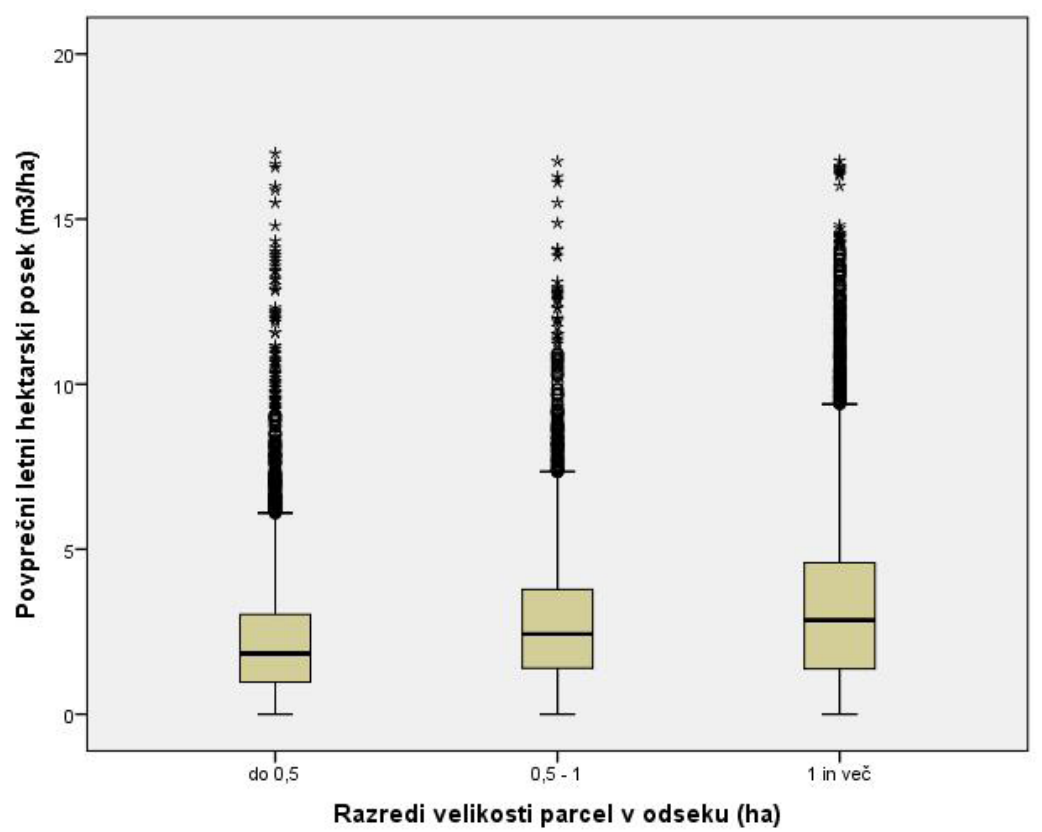

Slika 5: Povprečni letni hektarski posek glede na povprečno velikost parcele v odseku

Fig. 5: Mean annual timber harvesting in three categories of the mean plot size in the sub-compartment

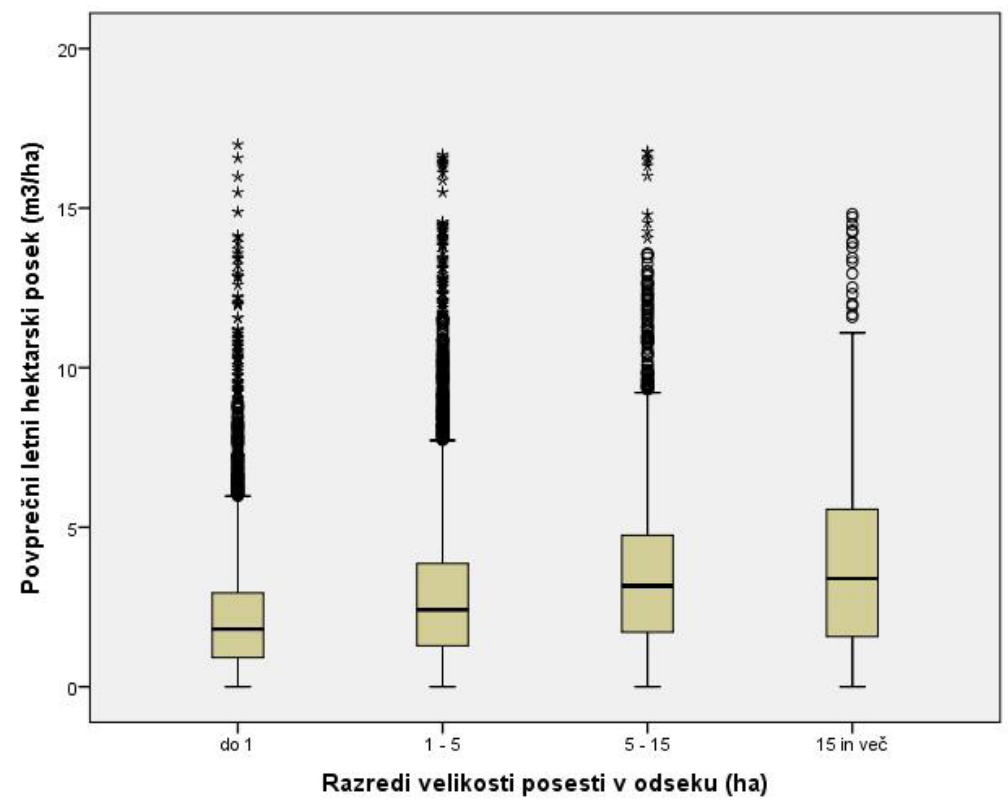

Slika 6: Povprečni letni hektarski posek glede na povprečno velikost posesti v odseku

Preglednica 5: Testiranje razlik v povprečni količini poseka glede na število (so)lastnikov v odseku
Fig. 6: Mean annual timber harvesting in four categories of mean property size in the sub-compartment

Table 5: Testing the difference in mean anual timber harvesting according to the number of (co)owners in the subcompartment

\begin{tabular}{|l|c|c|c|c|c|}
\hline & $\begin{array}{c}\text { Vsota kvadratov odklonov } \\
\text { Sum of squares }\end{array}$ & $\begin{array}{c}\text { Stopinje prostosti } \\
\text { Degrees of freedom }\end{array}$ & $\begin{array}{c}\text { Povprečni kvadrat } \\
\text { Mean square }\end{array}$ & $\begin{array}{c}F \\
\text { F-value }\end{array}$ & $\begin{array}{c}\text { Stopnja značilnosti } \\
\text { p-value }\end{array}$ \\
\hline Med razredi / Between & 2924 & 2 & 1462,331 & 271,972 & 0,000 \\
\hline Znotraj razredov / Within & 87270 & 16231 & 5,377 & & \\
\hline Skupaj / Total & 90195 & 16233 & & & \\
\hline
\end{tabular}




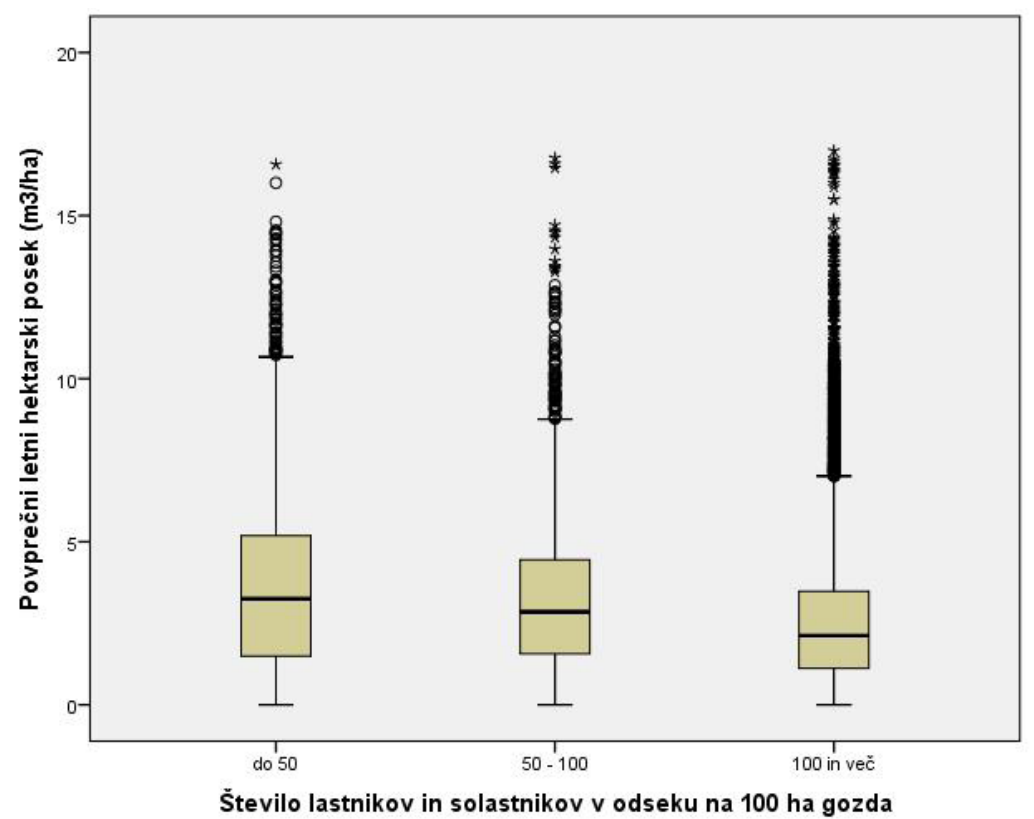

Slika 7: Povprečni letni hektarski posek glede na število lastnikov in solastnikov v odseku na 100 ha gozda

Ugotovili smo, da večje število lastnikov in solastnikov v odseku zmanjšuje povprečni letni hektarski posek. Povprečni letni posek se značilno razlikuje med vsemi tremi velikostnimi razredi števila (so)lastnikov (preglednica 5).

S tveganjem, manjšim od $5 \%$, lahko zavrnemo ničelno hipotezo: »Ni razlik v srednjih vrednostih poseka med tremi velikostnimi razredi števila (so)lastnikov na 100 ha gozda v odseku. «S Tamhanovim »post hoc« T2testom smo potrdili, da so razlike v srednjih vrednostih med vsemi tremi velikostnimi razredi (so)lastnikov.

Preglednica 6: Vpliv neodvisnih spremenljivk na odvisno spremenljivko POSEK
Fig. 7: Mean annual timber harvesting according to the number of owners and co-owners in a sub-compartment per 100 ha of forest

\subsection{Vplivni dejavniki količine poseka in srednje-} ga posekanega drevesa

3.2 Predictors of timber harvesting and the mean cubic tree

$\mathrm{Z}$ multiplo linearno regresijo smo ugotovili, da na POSEK statistično značilno vpliva 12 od vseh vključenih spremenljivk. Največji pozitiven vpliv ima delež smreke v odseku, največji negativni vpliv ima naklon (preglednica 6). Model se zadovoljivo prilega podatkom $\left(\mathrm{R}^{2}=0,210\right.$, prilagojeni $\mathrm{R}^{2}=0,209$, ostanki so rahlo asimetrični v levo, kar je posledica odsekov »osamelcev«, kjer posek odstopa navzgor, povprečni stan-

Table 6: The influence of independent variables on the dependent variable POSEK

\begin{tabular}{|c|c|c|c|c|c|c|c|}
\hline \multirow{2}{*}{$\begin{array}{l}\text { Model } \\
\text { Model }\end{array}$} & \multicolumn{2}{|c|}{$\begin{array}{l}\text { Nestandardizirani koeficienti } \\
\text { Unstandardized coefficients }\end{array}$} & \multicolumn{2}{|c|}{$\begin{array}{l}\text { Standardizirani koeficienti } \\
\text { Standadized coefficients }\end{array}$} & \multirow{2}{*}{$\begin{array}{l}\text { Stopnja značilnosti } \\
p \text {-value }\end{array}$} & \multicolumn{2}{|c|}{$\begin{array}{c}\text { Statistika kolinearnosti } \\
\text { Colinearity statistics }\end{array}$} \\
\hline & $\begin{array}{l}B \\
B\end{array}$ & $\begin{array}{c}\text { Standardna napaka } \\
\text { Standard error }\end{array}$ & $\begin{array}{l}\text { Beta } \\
\text { Beta }\end{array}$ & $\begin{array}{l}\mathrm{T} \\
t\end{array}$ & & $\begin{array}{l}\text { Toleranca } \\
\text { Tolerance }\end{array}$ & $\begin{array}{l}\text { VIF } \\
\text { VIF }\end{array}$ \\
\hline (Konstanta) & 0,746 & 0,121 & & 6,168 & 0,000 & & \\
\hline SM & 0,025 & 0,001 & 0,306 & 30,592 & 0,000 & 0,487 & 2,054 \\
\hline NAK & $-0,047$ & 0,002 & $-0,175$ & $-21,017$ & 0,000 & 0,701 & 1,427 \\
\hline PPS & 0,203 & 0,010 & 0,168 & 21,107 & 0,000 & 0,767 & 1,304 \\
\hline PARC & 0,088 & 0,004 & 0,162 & 20,465 & 0,000 & 0,780 & 1,281 \\
\hline RAZD_C & $-0,001$ & 0,000 & $-0,083$ & $-11,164$ & 0,000 & 0,878 & 1,140 \\
\hline RAZD_GR & 0,000 & 0,000 & 0,093 & 11,683 & 0,000 & 0,771 & 1,297 \\
\hline ODP & 0,007 & 0,001 & 0,072 & 8,984 & 0,000 & 0,754 & 1,327 \\
\hline RAZD_N & $-0,000$ & 0,000 & $-0,053$ & $-6,079$ & 0,000 & 0,651 & 1,535 \\
\hline SOLAST & 0,000 & 0,000 & $-0,042$ & $-5,784$ & 0,000 & 0,922 & 1,084 \\
\hline SM_POT & $-0,011$ & 0,002 & $-0,046$ & $-5,491$ & 0,000 & 0,688 & 1,453 \\
\hline SUKC & $-0,011$ & 0,002 & $-0,036$ & $-4,985$ & 0,000 & 0,940 & 1,063 \\
\hline $\mathrm{BU}$ & 0,003 & 0,001 & 0,028 & 3,078 & 0,002 & 0,584 & 1,712 \\
\hline
\end{tabular}


Preglednica 7: Vpliv neodvisnih spremenljivk na odvisno spremenljivko SD
Table 7: The influence of independent variables on the dependent variable SD

\begin{tabular}{|c|c|c|c|c|c|c|c|}
\hline \multirow{2}{*}{$\begin{array}{l}\text { Model } \\
\text { Model }\end{array}$} & \multicolumn{2}{|c|}{$\begin{array}{l}\text { Nestandardizirani koeficienti } \\
\text { Unstandardized coefficients }\end{array}$} & \multicolumn{2}{|c|}{$\begin{array}{l}\text { Standardizirani koeficienti } \\
\text { Standadized coefficients }\end{array}$} & \multirow{2}{*}{$\begin{array}{c}\text { Stopnja značilnosti } \\
\text { p-value }\end{array}$} & \multicolumn{2}{|c|}{$\begin{array}{c}\text { Statistika kolinearnosti } \\
\text { Colinearity statistics }\end{array}$} \\
\hline & $\begin{array}{l}B \\
B\end{array}$ & $\begin{array}{c}\begin{array}{c}\text { Standardna napaka } \\
\text { Standard error }\end{array} \\
\end{array}$ & $\begin{array}{l}\text { Beta } \\
\text { Beta }\end{array}$ & $\begin{array}{l}\mathrm{T} \\
t\end{array}$ & & $\begin{array}{l}\text { Toleranca } \\
\text { Tolerance }\end{array}$ & $\begin{array}{l}\text { VIF } \\
\text { VIF }\end{array}$ \\
\hline (Konstanta) & 0,083 & 0,026 & & 3,196 & 0,001 & & \\
\hline PPS & 0,058 & 0,002 & 0,229 & 28,778 & 0,000 & 0,835 & 1,198 \\
\hline \begin{tabular}{|l} 
RAZD_GR \\
\end{tabular} & 0,000 & 0,000 & 0,114 & 13,902 & 0,000 & 0,781 & 1,281 \\
\hline SM & 0,002 & 0,000 & 0,142 & 14,149 & 0,000 & 0,526 & 1,902 \\
\hline ODP & 0,002 & 0,000 & 0,099 & 11,671 & 0,000 & 0,738 & 1,354 \\
\hline $\mathrm{BU}$ & 0,001 & 0,000 & 0,074 & 7,840 & 0,000 & 0,587 & 1,703 \\
\hline PARC & 0,008 & 0,001 & 0,067 & 8,314 & 0,000 & 0,816 & 1,225 \\
\hline RAZD_C & 0,000 & 0,000 & $-0,060$ & $-7,801$ & 0,000 & 0,879 & 1,138 \\
\hline SKA & 0,004 & 0,000 & 0,081 & 8,948 & 0,000 & 0,639 & 1,566 \\
\hline SOLAST & 0,000 & 0,000 & $-0,056$ & $-7,436$ & 0,000 & 0,920 & 1,086 \\
\hline SUKC & $-0,003$ & 0,000 & $-0,047$ & $-6,219$ & 0,000 & 0,937 & 1,068 \\
\hline KAM & $-0,002$ & 0,000 & $-0,039$ & $-4,255$ & 0,000 & 0,641 & 1,561 \\
\hline NAK & 0,002 & 0,000 & 0,027 & 3,125 & 0,002 & 0,704 & 1,420 \\
\hline
\end{tabular}

dardizirani ostanek je enak 0 , ni zaporedne korelacije ostankov (Durbin-Watsonov test).

$\mathrm{Z}$ multiplo linearno regresijo smo preverjali, kateri dejavniki močno vplivajo na velikost povprečnega posekanega drevesa (SD). Ugotovili smo, da vse neodvisne spremenljivke razen SM_POT in RAZD_N statistično vplivajo na SD. Največji vpliv imata pričakovano proizvodna sposobnost rastišča in delež smreke v lesni zalogi (preglednica 7). Povprečni standardizirani ostanek je enak 0. Ostanki so rahlo asimetrični v pozitivno smer. Durbin-Watsonov test je pokazal, da ni zaporedne korelacije ostankov. Delež pojasnjene variance je 14,6 \%.

\section{RAPRAVA}

\section{DISCUSSION}

Rezultati vseh opravljenih statističnih testov potrjujejo prvo hipotezo, ki domneva, da je posek v zasebnih gozdovih različen glede na stopnjo razdrobljenosti zasebnih gozdov. Pričakovali smo, da je posek v razdrobljeni posesti manjši kot v relativno večji posesti, vendar veliko raziskav o vplivu razdrobljenosti posesti na posek ni bilo opravljenih. Razdrobljenost zasebne posesti smo merili s spremenljivkami povprečna velikost parcele v odseku, povprečna velikost posesti v odseku in število lastnikov s solastniki v odseku na 100 ha. Izkazalo se je, da velikosti parcele in posesti pozitivno vplivata na letni hektarski posek, saj se je s povečevanjem velikosti parcele in posesti povečeval tudi posek, medtem ko se je s povečevanjem števila (so)lastnikov zmanjševal.

Raziskava je zaradi razpoložljivosti podatkov potekala na ravni odsekov, ki so bili v popolni zasebni lasti. Vse tri spremenljivke razdrobljenosti zasebne posesti pojasnjujejo razlike $\mathrm{v}$ višini poseka in jih zato kaže uporabljati pri prognozah poseka v zasebnih gozdovih. Najenostavnejša spremenljivka razdrobljenosti je povprečna velikost parcele, zato se tudi pogosteje uporablja. Za opis posestnih razmer predlagamo novo spremenljivko, to je število solastnikov na standardizirani površini gozdov; ta mera podrobneje opisuje razdrobljenost zasebne posesti, saj lahko veliko število solastnikov pomembno vpliva na velikost poseka, predvsem pa otežuje gospodarjenje $\mathrm{z}$ zasebnimi gozdovi. Pri presojanju višine poseka po velikostnih razredih posesti je treba upoštevati, da to ni nujno dejanska velikost zasebnih posesti, ampak njihova velikost znotraj odsekov. Lastniki imajo lahko svojo posest v več odsekih ali celo različnih enotah in območjih.

Raziskava temelji na evidencah odkazila Zavoda za gozdove Slovenije, ki se lahko razlikujejo od dejanskih vrednosti poseka. Raziskave količine poseka na podlagi zaporednih meritev drevja na stalnih vzorčnih ploskvah $v$ testnih gozdnogospodarskih enotah so namreč pokazale, da je uradna količina poseka v gozdnogospodarskih enotah z zasebnimi gozdovi podcenjena (Bončina in sod., 2008; Medved in Matijašić, 2008). Po podatkih Zavoda za gozdove Slovenije je letni hektarski posek v zasebnih gozdovih v obdobju 1995-2017 po letih variiral $v$ intervalu $1,78 \mathrm{~m}^{3} /$ ha do $5,64 \mathrm{~m}^{3} / \mathrm{ha}$ (ZGS, 2018), nižji je bil v začetku obdobja, višji pa v letih velikih ujm. Vrednosti, ki smo jih v naši raziskavi ugotovili za razrede razdrobljenosti zasebne posesti, se zdijo logične; tako so za velikostne razrede parcel (do 0,5 ha; $0,5-1,0$ ha in $>1,0$ ha) v odsekih z izključno zasebnimi gozdovi vrednosti povprečnega hektarskega poseka $\mathrm{v}$ obdobju 1995-2014: 2,27 $\mathrm{m}^{3} / \mathrm{ha}, 2,81 \mathrm{~m}^{3} /$ ha in 3,32 $\mathrm{m}^{3} / \mathrm{ha}$. Istosmerna ugotovitev velja tudi za posek po velikostnih razredih zasebne posesti v odseku. 
Če bi nam uspelo pripraviti dovolj popolne podatke o poseku na ravni parcel in posestnikov, bi lahko preverili, ali drži ugotovitev o pozitivnem vplivu velikosti posesti in velikosti parcel na posek tudi na ravni posesti. Za družinske kmetije v Sloveniji, ki sestavljajo okoli 40 \% vseh zasebnih gozdov, je Medved (2010) ugotovil, da naj bi bil hektarski neto posek na majhni posesti precej večji od poseka na večjih posestvih. Po njegovih ocenah naj bi bil posek (leta 2007) na večjih posestvih (> 5 ha), merjen $v$ neto kubičnih metrih, okoli $3 \mathrm{~m}^{3} /$ ha; na majhni posesti ( $<1$ ha) pa približno kar trikrat večji, pri čemer pa ni jasno, ali so upoštevane vse družinske kmetije ali le tiste, na katerih so v analiziranem letu opravljali posek.

Zaradi možne podcenjene vrednosti poseka v zasebnih gozdovih so pomembna relativna razmerja $\mathrm{v}$ višini poseka med razredi razdrobljenosti zasebne gozdne posesti. Tako naša raziskava kaže, da je posek $\mathrm{v}$ zasebnih gozdovih $\mathrm{z}$ velikostjo parcel nad 1,0 ha in $\mathrm{v}$ gozdovih z velikostjo parcel $0,5-1,0$ ha kar za $46 \%$ oziroma za $24 \%$ večji kot v zasebnih gozdovih z velikostjo parcel, manjšo od 0,5 ha. Če to pokažemo z velikostjo posesti $\mathrm{v}$ odseku, potem je $\mathrm{v}$ primerjavi s posestjo $\mathrm{z}$ velikostjo do 1 ha letni hektarski posek v velikostnem razredu posesti 1-5 ha večji za $29 \%$, v razredu 5-15 ha večji za $58 \%$ in v razredu posesti nad 15 ha večji kar za 74 \%. Podobno kaže spremenljivka število solastnikov/100 ha gozda, saj je glede na gozdove s 100 in več solastniki na 100 ha večji za $28 \%$ v gozdovih, kjer je število solastnikov 50-100 na 100 ha, in za 41\% večji, če je število solastnikov manjše od 50 na 100 ha.

Omenjene relativne primerjave višine poseka temeljijo na srednjih vrednostih. Opazili pa smo veliko variabilnost poseka znotraj posameznih razredov velikosti parcel in posesti oziroma razredov števila solastnikov; v znatnem delu odsekov smo zabeležili vrednosti poseka, ki so znatno večje od srednje vrednosti poseka. V nadaljnjih raziskavah bi bilo treba raziskati, kaj vpliva na te odklone in ali gre za specifično skupino lastnikov.

Rezultate naše raziskave bi bilo mogoče preveriti in dopolniti z anketiranjem lastnikov; prednost anketiranja bi bila $v$ tem, da raziskava ne bi bila vezana na oddelek, saj bi anketirali posamezne lastnike, ki bi navedli velikost svoje celotne posesti, skupni posek in ostale pomembne informacije. Slabost takšne metode pa bi lahko bila manjša natančnost navedb o količini poseka za zadnje leto ali nekaj zadnjih let in številu solastnikov.

Višina poseka in velikost posesti sta lahko ena izmed podlag za klasifikacijo lastnikov in njihovih gozdov. Klasifikacije lastnikov gozdov, ki temeljijo na strukturnih značilnostih njihovih gozdnih posesti, prodaji lesa in intenzivnosti izkoriščanja možnega poseka (npr. Lönnstedt, 1989), so bile eden izmed najzgodnejših načinov prepoznavanja raznovrstnosti gozdnogospodarskih ciljev v zasebni posesti. Temeljni razlog za tovrstno razvrščanje lastnikov je bila potreba lesnopredelovalne industrije po surovini in povečano povpraševanje po okroglem industrijskem lesu v državah z znatnim deležem zasebnih gozdov (Reunala, 1974; Ficko et al., 2017): tedaj je postalo očitno, da vsi lastniki gozdov niso več kmetje in da poleg dobička zasledujejo še druge cilje. Najnovejši pregled tipov lastnikov zasebnih gozdov v Evropi (Ficko et al., 2017) kaže, da postaja ta skupina vse bolj raznolika in da pridobivanje lesa izgublja pomen v primerjavi z drugimi cilji. Med lastniki obstajajo tudi znatne regionalne razlike, ki jih lahko deloma pojasnimo z odnosom družbe do naravnega okolja, z zgodovino urejanja gozdov in političnimi spremembami v državah v tranziciji (Feliciano et al., 2017).

Velike variabilnosti v količini poseka med velikostnimi razredi zasebne gozdne posesti nakazujejo, da na višino poseka vplivajo tudi drugi dejavniki. V drugem delu naše raziskave se je izkazalo, da vse neodvisne spremenljivke, vključene v model, razen kamnitosti in skalovitosti, vplivajo na višino poseka. S tem smo potrdili hipotezo, da na višino in strukturo poseka poleg velikosti in razdrobljenosti posesti vplivajo naravni, gozdnogospodarski (dostopnost) in socioekonomski dejavniki.

Delež smreke v odseku je ena izmed vseh proučevanih spremenljivk, ki ima največji pozitiven vpliv. Smreka je ekonomsko zanimiva in zato pospeševana drevesna vrsta, njen delež je zaradi vsaj ponekod obsežne umetne obnove smreke in tudi njenega pospeševanja $\mathrm{z}$ nego $\mathrm{v}$ mešanih gozdovih znatno višji od naravnega. Lesna zaloga sestojev z večjim deležem smreke je praviloma višja, zato je v takšnih gozdovih tudi načrtovani posek višji. V zasmrečenih sestojih lahko k višjemu poseku znatno prispeva sanitarni posek, predvsem ob gradaciji podlubnikov (Poljanec in sod., 2014). Med sestojnimi spremenljivkami je na višino poseka pričakovano negativno vplival delež pionirskih gozdov (SUKC); ti gozdovi imajo nižjo lesno zalogo, hkrati pa je gospodarjenje s temi gozdovi manj donosno. Ti gozdovi so deloma prepuščeni naravnemu razvoju, ali pa v njih potekajo ukrepi posredne premene šibke jakosti; vpliv te spremenljivke bi bil drugačen v primeru neposredne premene teh gozdov. Delež bukve pozitivno vpliva na višino poseka; višji delež bukve nakazuje visoke in bolj ohranjene gozdove (Bončina, 2012).

Od rastiščnih dejavnikov ima na višino poseka največji vpliv naklon (NAK). Posek se $\mathrm{z}$ večanjem naklona terena zmanjšuje. Na terenih $\mathrm{z}$ velikimi nakloni je 
pridobivanje lesa bistveno zahtevnejše in tudi dražje. Pozitiven vpliv produkcijske sposobnosti rastišč na višino poseka je pričakovan; produktivna rastišča omogočajo hitro rast in s tem večje prirastke (Kadunc in sod., 2013) ter večji posek. Pričakovano je, da se posek zmanjšuje z naraščanjem deleža smreke v naravni sestavi gozdnih združb (SM_POT). Smrekovja in združbe $\mathrm{z}$ naravnim velikim deležem smreke namreč uspevajo na manj ugodnih ali celo ekstremnejših rastiščih z nižjo produkcijsko sposobnostjo (Kadunc in sod., 2013).

Na višino poseka vplivajo spremenljivke dostopnosti; tako je posek manjši v gozdovih z manjšo stopnjo odprtosti z gozdnimi prometnicami (delež odprte površine), zmanjšuje se z oddaljenostjo gozdnih sestojev do gozdne ceste in z oddaljenostjo do naselij, medtem ko je vpliv oddaljenosti od gozdnega roba pozitiven. Delež odprte površine (ODP) se največkrat navezuje na omrežje gozdnih vlak; v predelih, kjer teh prometnic ni, je spravilo oteženo ali pa je nemogoče, kar seveda vpliva na višino poseka na ravni odsekov (Poje in sod., 2016). Gostota gozdnih cest vpliva na spravilne razdalje in s tem tudi na stroške pridobivanja lesa. Zato je razumljivo, da je gospodarjenje intenzivnejše na območjih, ki so bliže gozdnim cestam (RAZD_C). Razdalja do naselij (RAZD_N) je povezana s transportnimi razdaljami; naš rezultat kaže, da se z oddaljenostjo od naselij višina poseka v zasebnih gozdovih zmanjšuje.

Na prvi pogled presenetljiva je ugotovitev, da se $\mathrm{z}$ oddaljenostjo od gozdnega roba (RAZD_G) višina poseka povečuje. Ta relacija je lahko posledica dejstva, da so ob gozdnem robu zaradi spremembe zemljiške rabe (zaraščanje) ali močnejših človekovih vplivov pogostejši pionirski gozdovi (Bončina in sod., 2017), ki so manj zanimivi za gospodarjenje, lahko pa je to posledica preteklega intenzivnega izkoriščanja gozda na lahko dosegljivih mestih. Smiselna se zdi tudi domneva, da lastniki ne sekajo radi na gozdnem robu, kjer se sečnja vidi, ampak dlje stran, kar jim morda daje občutek, da ne posegajo premočno v svoje gozdne fonde.

Dve socioekonomski spremenljivki sta vključeni v model višine poseka v zasebnih gozdovih; z naraščanjem velikost parcel (PARC) se posek v zasebnih gozdovih opazno povečuje, medtem ko se $\mathrm{z}$ razdrobljenostjo posesti med solastnike (SOLAST) zmanjšuje.

Srednje posekano drevo kaže na stanje gozdnih sestojev in hkrati tudi njihovo gojitveno obravnavo. Od sestojnih spremenljivk ima delež smreke v odseku (SM) največji vpliv na srednje posekano drevo; to je pričakovano, saj smreka $\mathrm{v}$ primerjavi z naravnim drevesnimi vrstami listavcev dosega na istem rastišču večje dimenzije. $\mathrm{V}$ pionirskih gozdovih so dimenzije drevja praviloma manjše kot $\mathrm{v}$ ohranjenih, zato je ne- gativni vpliv deleža pionirskih gozdov (SUKC) pričakovan. Podobno velja za pozitiven vpliv deleža bukve v sestojih (BU) na srednje drevo; delež bukev je v bukovih gozdovih, ki v Sloveniji prevladujejo, lahko kazalnik ohranjenosti gozdov. Vpliv rastiščnih spremenljivk je pričakovan; na rodovitnejših rastiščih (PPS) je srednje posekano drevo večje; drevesa na takšnih rastiščih lahko (hitreje) dosegajo večje dimenzije, zato so tudi tarifni razredi za obračun volumnov večji. Z naraščanjem stopnje skalovitosti (SKA) in naklona (NAK) se srednje posekano drevo povečuje: pogosto so na takšnih terenih gozdovi manj spremenjeni kot na ugodnejših terenih, ki so bili primernejši za kmetijsko rabo, hkrati pa kaže na manj intenzivno gospodarjenje kot posledica večjih stroškov pridobivanja lesa. $\mathrm{V}$ gozdovih, ki so bolj odprti (ODP), in gozdovih, ki so bolj oddaljeni od naselij (RAZD_N), gozdnega roba (RAZD_G) in cest (RAZD_C), je srednje posekano drevo večje. Gre verjetno za bolj ohranjene gozdove. Podobne relacije smo ugotovili pri študiji vpliva teh spremenljivk na stopnjo ohranjenosti naravne drevesne sestave gozdov (Bončina in sod., 2017). Z večanjem parcel (PARC) se srednje posekano drevo povečuje; vpliv velikosti parcel je pričakovan, povezan s stanjem gozdov glede na posestno razdrobljenost. Število solastnikov (SOLAST) zmanjšuje povprečno posekano drevo, kar lahko pojasnimo kot slabše ohranjene gozdove, ki so bili izpostavljeni večjim potrebam po lesu v preteklosti.

\section{ZAKLJUČKI}

\section{CONLCUSIONS}

Ugotovili smo, da razdrobljenost zasebne posesti značilno vpliva na višino poseka; povprečni hektarski posek se z naraščajočo razdrobljenostjo posesti zmanjšuje. Na višino in strukturo poseka poleg socioekonomskih dejavnikov vplivajo sestojni, rastiščni in gozdnogospodarski dejavniki. Pomemben dejavnik, ki pozitivno vpliva na sečnjo v zasebnih gozdovih, je delež smreke. Pričakujemo, da bo tudi v bodoče delež iglavcev pomemben dejavnik, ki bo ohranjal sečnjo v zasebnih gozdovih.

Posek drevja v zasebnih gozdovih je relativno nizek, če ga primerjamo s prirastkom gozdnih sestojev. Glede na negativen vpliv razdrobljenosti in majhnosti posesti lahko ocenimo, da bi povezovanje zasebnih lastnikov gozdov in skupno gospodarjenje prispevalo $\mathrm{k}$ aktivnejšemu gospodarjenju z zasebnimi gozdovi.

Eden izmed ključnih dejavnikov pri zagotavljanju lesa iz zasebnih gozdov je tudi načelna pripravljenost lastnikov gozdov za gospodarjenje in njihov odnos do gozda. Tu pogosto prezremo, da z ekonometričnimi modeli ne moremo $\mathrm{v}$ celoti pojasniti vedenja lastnikov 
gozdov, saj takšni modeli ne vključujejo odnosov lastnikov do gozda in njihove pripravljenosti za posek, ampak zgolj pojasnjujejo, kakšen posek lahko pričakujemo ob naravnih in gozdnogospodarskih razmerah, gibanju tržnih cen lesa, cenah energentov, ukrepih politike in drugih makroekonomskih dogajanjih. Manjša aktivnost nekaterih lastnikov gozdov je lahko močno povezana $\mathrm{z}$ razumevanjem pojmov gospodarjenja in gospodarnosti. Zato bi v prihodnje v preučevanje poseka v zasebnih gozdovih kazalo vključiti tudi dejavnike, ki pojasnjujejo odnos lastnikov do narave. Tako bi pogosto zgolj deskriptivni pristop pri preučevanju vedenja lastnikov gozda nadgradili v kompleksnejše modeliranje.

\section{POVZETEK}

Raziskovali smo vpliv razdrobljenosti zasebne gozdne posesti ter drugih naravnih, gozdnogospodarskih in socioekonomskih dejavnikov na posek drevja v zasebnih gozdovih Slovenije. Ker pri nas velja ustaljeno in nepreverjeno prepričanje, da sta majhna posest in njena razdrobljenost glavna dejavnika za nizek posek v zasebnih gozdovih, smo želeli pojasniti dejavnike, ki vplivajo na višino poseka. Za analizo smo uporabili podatke Zavoda za gozdove Slovenije in podatkovne zbirke Skupine za urejanje gozdov in prirastoslovje. V programu Mapinfo smo pripravili podatkovno zbirko ZASEBNI GOZDOVI, ki obsega podatke na ravni odsekov ( $\mathrm{n}=16.234$; površina je 306.097 ha), ki so 100odstotno v zasebni lasti. Analizirali smo dve odvisni spremenljivki, in sicer povprečni letni hektarski posek (POSEK) in srednje drevo (SD). Za pojasnjevanje razlik v poseku glede na tip zasebne gozdne posesti smo izračunali tri neodvisne spremenljivke: povprečna velikost parcele v odseku (PARC), povprečna velikost posesti v odseku (POSEST) in povprečno število (so)lastnikov na 100 ha v odseku (SOLAST). Za obdelave z univariatnimi statističnimi testi smo nominalne neodvisne spremenljivke PARC, POSEST in SOLAST pretvorili v kategorialne; tvorili smo tri razrede za spremenljivki PARC in SOLAST ter štiri razrede za spremenljivko POSEST. Za izpeljavo multivariatnih statističnih testov, s katerimi smo ugotavljali vpliv neodvisnih spremenljivk na odvisni (POSEK, SD), pa smo v raziskavo vključili tudi naravne, gozdnogospodarske in socioekonomske neodvisne spremenljivke. Rezultati so pokazali, da razdrobljenost zasebne gozdne posesti negativno vpliva na povprečni letni hektarski posek. Ta se je namreč povečeval z večanjem velikosti parcel in posesti in zniževal s številom (so)lastnikov v odseku. Povprečna vrednost letnega poseka $v$ velikostnem razredu do 0,5 ha velikosti parcele je znašala $2,27 \mathrm{~m}^{3}$ /ha, medtem ko je v velikostnem razredu 1 ha in več znašala 3,32 $\mathrm{m}^{3}$ /ha. Z multivariatnimi testi smo ugotovili, da na posek vplivajo mnogi naravni, gozdnogospodarski in socioekonomski dejavniki. Na POSEK najbolj vpliva delež smreke v odseku, ki ima pozitiven vpliv. Prav tako so imele znaten pozitiven vpliv še spremenljivke potencialne produkcijske sposobnosti, velikosti parcele in razdalja do gozdnega roba, medtem ko sta naklon in razdalja do ceste imela znaten negativen vpliv. Pri preverjanju vpliva neodvisnih spremenljivk na srednje drevo SD se je pokazalo, da ima največji pozitiven vpliv potencialna produkcijska sposobnost rastišča. Znaten pozitiven vpliv so imele še razdalja do gozdnega roba, delež smreke $\mathrm{v}$ odseku in odprtost. $\mathrm{Z}$ raziskavo smo pokazali, da razdrobljenost zasebne gozdne posesti vpliva na letni posek. Analiza podatkov kaže veliko variabilnost poseka znotraj posamezne kategorije velikosti parcel (posesti in števila lastnikov), v znatnem delu odsekov smo zabeležili vrednosti poseka, ki so znatno večja od srednje vrednosti poseka. V nadaljnjih raziskavah bi bilo treba raziskati, ali gre za posebno skupino lastnikov, ki sekajo nadpovprečno veliko.

\section{SUMMARY}

We analyzed how fragmentation of private forest property and other natural, forest management and socio-economic factors influence timber harvesting in private forests in Slovenia. There is an established and unverified belief that small property and high fragmentation are the main factors for low harvesting in private forests, but no study has been carried out at the national level to verify this. For the analysis, we used the data of the Slovenia Forest Service and the databases of the Chair for Forest Management, Planning and Ecosystem Analysis. In the MapIinfo program, we prepared PRIVATE FORESTS database, which includes data at the sub-compartment level ( $\mathrm{n}=16,234$; the area is $306,097 \mathrm{ha}$ ), which are $100 \%$ privately owned. We analyzed two dependent variables, mean annual timber harvesting per hectare (POSEK) and mean cubic tree (SD). To explain the differences in timber harvesting according to the type of private forest property, we calculated three independent variables: the average size of the plot in the sub-compartment (PARC), the average size of the property in the sub-compartment (POSEST), and the average number of (co)owners per 100 ha in the sub-compartment (SOLAST). For univariate statistical tests, the nominal independent variables PARC, POSEST and SOLAST were converted into categorical; we created three classes for the variables PARC and SOLAST and four classes for the variable POSEST. In multivariate statistical tests we also tested the influence of natural, forest-management and socioe- 
conomic independent factors. The results showed that the fragmentation of private forest property negatively impacts harvesting rates per hectare. Harvesting increased with the increase of the size of plots and property and decreased with the number of (co)owners in the sub-compartment. The mean timber harvesting in the sub-compartments with mean size of plots up to 0.5 ha was $2.27 \mathrm{~m}^{3} / \mathrm{ha}$, while in the size class of 1 ha and more it amounted to $3.32 \mathrm{~m}^{3} / \mathrm{ha}$. Using multivariate tests we found that many natural, forest management and socioeconomic factors influence timber harvesting. The share of spruce in the sub-compartment has the greatest (positive) impact on POSEK. Also, the size productivity, the size of the plots and the distance to the forest edge had a significant positive impact, while the inclination and the distance to the nearest road had a significant negative impact. In studying the influential factors of the mean cubic tree, we found that site productivity has the greatest positive impact. Significant positive impact also had the distance to the forest edge, the share of spruce in the sub-compartment, and openness. The analysis showed that the fragmentation of private forest properties has a significant effect on timber harvesting. Data shows a high variability of harvesting within each category of plot size, property size and number of owners, and in a significant part of the sub-compartments harvesting rates were significantly higher than the mean. Further research should explore whether there is a special type of forest owners who regularly cut above the average.

\section{VIRI}

\section{REFERENCES}

Bončina A. (ur.). 2012. Bukovi gozdovi v Sloveniji : ekologija in gospodarjenje. Ljubljana, Oddelek za gozdarstvo in obnovljive gozdne vire, Biotehniška fakulteta, 469 str.

Bončina A., Hladnik D., Kadunc A. 2008. Presoja ocenjevanja količine poseka na podlagi periodičnih meritev na stalnih vzorčnih ploskvah. Gozdarski vestnik, 68, 3: 135-144.

Bončina A., Klopčič M., Simončič T., Dakskobler I., Ficko A., Rozman A. 2017. A general framework to describe the alteration of natural tree species composition as an indicator of forest naturalness. Ecological Indicators, 77: 194-204.

Češarek D. 2017. Značilnosti poseka v zasebnih gozdovih Slovenije v obdobju 1995-2014. Magistrsko delo, Biotehniška fakulteta, Oddelek za gozdarstvo in obnovljive gozdne vire, Ljubljana.

Erzetič G. 2010. Analiza načrtovanega poseka v Sloveniji v letu 2006. Diplomsko delo. Biotehniška fakulteta, Oddelek za gozdarstvo in obnovljive gozdne vire, Ljubljana.

Feliciano D., Bouriaud L., Brahic E., Deuffic P., Dobsinska Z., Jarsky V., Lawrence A., Nybakk E., Quiroga S., Suarez C., Ficko A. 2017. Understanding private forest owners' conceptualisation of forest management: Evidence from a survey in seven European countries. Journal of Rural Studies, 54: 162-176.

Ficko A., Lidestav G., Ní Dhubháin Á., Karppinen H., Zivojinovic I., Westin K. 2017. European private forest owner typologies: A review of methods and use. Forest Policy and Economics. In press.
IBM SPSS Statistics 20. 2011. New York, IBM Corporation (izpis iz baze podatkov, 20. apr. 2017).

Jakša J. 2012. Prednosti skupnega gospodarjenja z gozdovi, izziv za delo v zasebnih gozdovih. V: Povezovanje lastnikov gozdov in skupno gospodarjenje. 29. gozdarski študijski dnevi, Ljubljana, 22. november 2012. Ljubljana, Biotehniška fakulteta, Oddelek za gozdarstvo in obnovljive gozdne vire: 1-2.

Kadunc A., Poljanec, A., Dakskobler I., Rozman A., Bončina A. 2013. Ugotavljanje proizvodne sposobnosti gozdnih rastišč v Sloveniji. Vsebinsko poročilo o realizaciji projekta. Oddelek za gozdarstvo in obnovljive gozdne vire, Biotehniška fakulteta, Ljubljana.

Lönnstedt L. 1989. Goals and cutting decisions of private small forest owners. Scandinavian Journal of Forest Research, 4 (1-4): 259-265.

Mapinfo Proffesional, Version 12.0.2. 2013. Connecticut, Pitney Bowes Postage Meter Company (izpis iz baze podatkov, 15. mar. 2017).

Marenče J., Pezdevšek Malovrh Š., Krč J. 2012. Organizacija in tehnologija izkoriščanja gozdov in njun prispevek v realizaciji možnega poseka v zasebnih gozdovih. Gozdarski vestnik, 70, 4: 183-188.

Max W., Lehman D. 1988. A behavioral model of timber supply. Journal of Environmental Economics and Management, 15: 71-86.

Medved M. 2010. Pridobivanje lesa na družinskih kmetijah v Sloveniji. Gozdarski vestnik, 68, 1: 83-95.

Medved M., Matijašić D. 2008. Spremljanje poseka pri gospodarjenju z gozdovi. Gozdarski vestnik, 66, 1: 49-64.

Medved M., Matijasic D., Pisek R. 2010. Private property conditions of Slovenian forests: preliminary results from 2010. V: Small scale forestry in a changing world: opportunities and challenges and the role of extension and technology transfer: proceedings of the conference. Medved M. (Ur.). Ljubljana, Slovenian Forestry Institute, Slovenia Forest Service: 457-472.

Poje A., Pezdevšek Malovrh Š., Krč J, 2016. Factors affecting harvesting intensity in small-scale private forests in Slovenia. SmallScale Foresty, 15, 1: 73-91.

Poljanec A., Ščap Š., Bončina A. 2014. Količina, struktura in razporeditev sanitarnega poseka v Sloveniji v obdobju 1995-2012. Gozdarski vestnik, 72, 3: 131-147.

Poročilo o izvajanju Nacionalnega gozdnega programa do 2014. 2016. Ljubljana, Ministrstvo za kmetijstvo, gozdarstvo in prehrano: 97 str.

Poročilo Zavoda za gozdove Slovenije o gozdovih za leto 2016. 2017. Ljubljana, Zavod za gozdove Slovenije: 128 str.

Reunala A., 1974. Structural change of private forest ownership in Finland. Communicationes Instituti Forestalis Fenniae 82, 2, 79 p.

UGB. 2015. Podatkovna zbirka Skupine za urejanje gozdov in ekosistemske analize. Ljubljana, Biotehniška fakulteta, Oddelek za gozdarstvo in obnovljive gozdne vire (izpis iz baze podatkov, 10 . mar. 2017).

Winkler I. 1976. Sedanje stanje in temeljni problemi gospodarjenja $\mathrm{z}$ zasebnimi gozdovi v SR Sloveniji. Zbornik gozdarstva in lesarstva, 14, 2: 123-154.

Winkler I., Medved M. 1994. Spremembe lastninske strukture gozdov zaradi denacionalizacije in njihove gozdnogospodarske posledice. Zbornik gozdarstva in lesarstva, 44: 215-246.

ZGS. 2014. Podatkovne zbirke: Timber, Odsek, Odsgzd, Odsses, Odssesdv, Odssesgzd. Ljubljana, Zavod za gozdove Slovenije (izpis iz baze podatkov, 24. feb. 2017).

ZGS. 2018. Hektarski letni posek v zasebnih gozdovih Slovenije v obdobju 1995-2017. Excel podatkovna zbirka. Zavod za gozdove Slovenije, Oddelek za gozdnogospodarsko načrtovanje, Ljubljana. 
Priloga 1: Letni hektarski posek v zasebnih gozdovih Slovenije v obdobju 1995-2014 glede na velikost parcel in posesti ter število solastnikov v odsekih
Appendix 1: Annual timber harvesting in private forests in Slovenia within the 1995-2014 period according to the size of the plots, property size and the number of (co)owners

\begin{tabular}{|c|c|c|c|c|c|}
\hline $\begin{array}{c}\text { Struktura zasebne posesti } \\
\text { Private forest property conditions }\end{array}$ & $\begin{array}{c}\text { Aritmetična sredina } \\
\left(\mathrm{m}^{3} / \mathrm{ha}\right) \\
\text { Arithmetic mean } \\
\left(\mathrm{m}^{3} / \mathrm{ha}\right)\end{array}$ & $\begin{array}{l}\text { Standardni odklon } \\
\left(\mathrm{m}^{3} / \mathrm{ha}\right) \\
\text { Standard deviation } \\
\left(\mathrm{m}^{3} / \mathrm{ha}\right)\end{array}$ & $\begin{array}{c}\text { Mediana } \\
\left(\mathrm{m}^{3} / \mathrm{ha}\right) \\
\text { Median }\left(\mathrm{m}^{3} / \mathrm{ha}\right)\end{array}$ & $\begin{array}{l}\text { Prvi kvartil } \\
\left.\mathrm{m}^{3} / \mathrm{ha}\right) \\
\text { Q1 (m³a) }\end{array}$ & $\begin{array}{c}\text { Tretji kvartil } \\
\left(m^{3} / h a\right) \\
\text { Q3 }\left(m^{3} / h a\right)\end{array}$ \\
\hline \multicolumn{6}{|c|}{ Velikostni razred parcele (ha) / Mean size of plots in the compartment (ha) } \\
\hline Do / up to 0,5 & 2,27 & 1,99 & 1,84 & 0,97 & 3,02 \\
\hline $0,5-1$ & 2,81 & 2,08 & 2,43 & 1,39 & 3,78 \\
\hline 1 in več / and more & 3,32 & 2,66 & 2,85 & 1,37 & 4,59 \\
\hline \multicolumn{6}{|c|}{ Velikostni razred posesti (ha) / Mean size of private forest property in the compartment (ha) } \\
\hline Do / up to 1 & 2,22 & 2,01 & 1,81 & 0,92 & 2,94 \\
\hline $1-5$ & 2,86 & 2,28 & 2,41 & 1,29 & 3,86 \\
\hline $5-15$ & 3,50 & 2,57 & 3,17 & 1,71 & 4,75 \\
\hline 15 in več / and more & 3,86 & 3,03 & 3,39 & 1,56 & 5,56 \\
\hline \multicolumn{6}{|c|}{ Število (so)lastnikov/100 ha gozda / Number of (co)owners per 100 ha of forest } \\
\hline do / up to 50 & 3,65 & 2,84 & 3,25 & 1,49 & 5,18 \\
\hline $50-100$ & 3,29 & 2,47 & 2,85 & 1,57 & 4,45 \\
\hline 100 in več / and more & 2,58 & 2,15 & 2,13 & 1,12 & 3,48 \\
\hline
\end{tabular}

